\title{
A proposta metodológica da fotografia como disparadora do gatilho da memória: aplicação à história de Telêmaco Borba - PR (1950-1969)
}

\author{
Autor: Juliana de Oliveira Teixeira \\ Orientador: Prof. Dr. Paulo César Boni
}

\begin{abstract}
Resumo: Este trabalho tem como objetivo testar e sistematizar a proposta metodológica do uso da fotografia como elemento disparador do gatilho da memória, técnica que alia a imagem fotográfica à história oral. O método, desenvolvido pelo grupo Comunicação e História da Universidade Estadual de Londrina, foi formalizado na dissertação de mestrado de Maria Luisa Hoffmann (2010) e, desde então, tem sido aplicado em municípios de trajetória recente. Para que o teste desta dissertação fosse, de fato, pertinente, o município de Telêmaco Borba (PR) foi escolhido como campo de estudo, e os preceitos do empirismo em comunicação foram respeitados em seus rigores, pautados nas concepções de Maria Immacolata Vassallo Lopes (2010) e Luiz Claudio Martino (2010). A aplicação do método também foi fundamentada teoricamente, utilizando como referência as obras de Jacques Le Goff(2003), Ecléa Bosi (2009) e Boris Kossoy (2009). Durante o processo empírico, nove pioneiros telemacoborbenses foram submetidos à proposta metodológica, com a utilização de 17 fotografias de época da cidade. Em linhas gerais, os resultados alcançados demonstram que a técnica, se aplicada de acordo com os critérios epistemológicos inerentes à ciência, transforma-se em uma eficiente ferramenta empírica, capaz de trazer novos dados e informações ao estudo da memória e à história dos municípios pesquisados.
\end{abstract}

Palavras-chave: Fotografia e Memória. Gatilho da memória. História de Telêmaco Borba (PR). 


\title{
The methodological proposal of photography as a discharger of the trigger of memory: application to Telêmaco Borba s history (1950-1969)
}

\begin{abstract}
This work has the objectives of testing and systematizing the methodological proposal of photography as a discharger of the trigger of memory, a technique that combines photographic images with oral history. The method, developed by the group Communication and History of Universidade Estadual de Londrina, was formalized in the dissertation of Maria Luisa Hoffmann (2010) and, since then, it has been applied to cities with recent histories. To do a relevant test in this dissertation, Telêmaco Borba $(P R)$ was chosen as field of study, and the precepts of empiricism in communication were respected, following the ideas of Maria Immacolata Vassallo Lopes (2010) and Luiz Claudio Martino (2010). The application of the method was also based theoretically, using as references the works of Jacques Le Goff(2003), Ecléa Bosi (2009) and Boris Kossoy (2009). During the empirical process, nine pioneers of Telemaco Borba were submitted to the methodological proposal, using 17 old photographs of the city. Roughly, the results of the test show that the technique, when applied with the epistemological criteria of science, becomes an efficient empirical tool, capable of bringing new data and information to the studies of memory and to the history of the studied cities.
\end{abstract}

Keywords: Photography and Memory. Trigger of memory. History of Telêmaco Borba $(P R)$.

Dissertação completa disponível em: http://www.uel.br/pos/ mestradocom unicacaolwp-content/uploads / Disserta\%C3\%A7\%C3\%A3o_Juliana-Teixeira.pdf 